\title{
GUEST EDITORIAL: Familial transmission, support, and youth employment in hard economic times
}

Jeylan T Mortimer, University of Minnesota, USA

morti002@umn.edu

(Received December 2013 Revised March 2013)

http://dx.doi.org/10.14301/Ilcs.v5i2.283

Keywords: family, parental support, economic hardship, youth unemployment

The recent 'Great Recession' started with the United States' fiscal crisis of December 2007 and quickly spread to Europe and other parts of the world. Though it has officially ended in many places (in June 2009 in the United States), it continues to have severe impacts on the lives of young people. Even by June of 2013, five years after the recession began, youth continued to suffer severe economic setbacks. Southern Europe was still hit particularly hard, with unemployment rates among 15-24 year olds reaching $58 \%$ in Greece, $55 \%$ in Spain, $40 \%$ in Portugal, and $38 \%$ in Italy (Alderman, 2013). Many unemployed and marginally employed youth from Southern Europe, especially those with skills and post-secondary degrees, have migrated to northern European countries seeking employment, only to occupy a succession of temporary, low-paying and part-time jobs and unpaid internships, interspersed with periods of joblessness. Youth unemployment in Northern Europe and the United States was not as severe, but still high by historic standards---for example, $29 \%$ for $15-24$ year olds in Ireland, $21 \%$ in Britain, and $16 \%$ in the United States (16-24 year olds). In contrast, Germany, with its still functioning, though threatened, apprenticeship system, was quite successful in protecting its young people throughout the recession, as evidenced by its very low, $8 \%$ rate of youth unemployment in 2013.

Many European and North American youth have given up dreams of pursuing professional and managerial careers. Analysts continue to refer to a "lost generation" of young people, fearing that even when prosperity returns, it will be younger cohorts who benefit the most, not those who missed out on opportunities for human capital development and career mobility in the years immediately after completing their formal educations. Economists and sociologists worry about so-called "NEETs," those young people who are not in employment, education, or training, and, as a result, not investing in their human capital. It is estimated that these youth encompass 14 million young Europeans (Alderman, 2013). In the United States, by the end of 2010 the employment to population ratio among youth aged 16-29 was at its lowest point since World War II, 55\% (Children's Defense Fund, 2011). As a result of their precarious position in the labor market, many young adults have experienced increases in living at home with their parents, and declines in marriage and birth rates (Sobotka, Skirbekk, \& Philipov, 2011; Newman, 2012).

This "Special Section" on "Youth, Economic Hardship, and the Worldwide 'Great Recession' grew out of an initiative begun by John Bynner, Glen Elder, and Walter Heinz in 2009 in the wake of the financial collapse and ensuing economic turmoil. The Youth in the Great Recession initiative (YGR) built on Glen Elder's monumental study of Children of the Great Depression (Elder, 1974; Elder \& Rockwell, 1979), which demonstrated the long-term significance of depression hardship for children's socialization to work, their work value formation, and their future socio-economic careers. The leaders of the "Youth in the Great Recession Initiative" were surely prescient in envisioning the difficulties youth would face during, and following, this most recent worldwide economic cataclysm. 
Whereas hard economic times pose difficulties for persons of all ages, youth who are entering the fulltime labor force are particularly hard hit, as their inability to obtain stable remunerative employment lessens the likelihood of successfully completing normative early adult transitions, such as marriage, parenting, and independent residence. Plans were made for the initiative to consider both immediate and long-term effects. How might deterioration in their parents' economic circumstances affect young people's orientations to their futures and capacity to undertake a successful transition from school to work? Might ever more youth be mired in persistent poverty?

Would the uncertainty posed by unstable labor market opportunities lead youth to postpone transitions to adulthood, and to be more risk-averse generally? Or might the same conditions promote a more proactive, independent, entrepreneurial, and creative approach to life situations and opportunities?

The founders of the YGR recognized the need for research to fully understand the consequences of contemporary economic events in diverse societal contexts. They envisioned a tri-nation study of the impacts of the recession on youth in the United States, Germany, and Great Britain. The worldwide scope of the "Great Recession" enables comparison of differences in the impacts of economic hardship on families and individuals, across nations characterized by different institutional structures that could render young people more or less vulnerable. Given the structural differences across these countries - in the structure of educational and vocational qualifications, the school-to-work transition, the provision of societal safety net protection, and cultural values - a comparative study could reveal what difference the socio-cultural context makes for youth's successful transition to adulthood in unfavorable economic times.

Meetings in London and Munich were held in the Spring of 2010 to discuss the consequences of economic turmoil for young people in distinct social settings and to consider strategies to obtain the resources to support future collaborative work. These meetings were followed in May 2011 by a conference organized by Jacquelynne Eccles at the University of Michigan, and supported by the Society for Research on Child Development. The interdisciplinary consortium of scholars assembled in Ann Arbor included psychologists, sociologists, demographers, economists, and policy analysts. The intent was to examine the impacts of the 'Great Recession' on youth themselves as they navigated the transition, as well as the more indirect consequences for young people that operated through the "linked lives" (Elder, Johnson, \& Crosnoe, 2003) of parents and children. That is, parents' economic circumstances could have lasting consequences for children, adolescents, and older youth as they formed their aspirations and plans for the future and attempted to progress in their pathways to adulthood.

The participants at the Ann Arbor meeting were invited to share their ongoing research, as well as to explore the potentials of the data sets they were working with for cross-national comparison. A set of complementary collaborative projects was envisioned, some involving national longitudinal data sets. One of these would comprise the Panel Study of Income Dynamics in the United States, the German Socio-Economic Panel, and the British Household Panel Study, enabling comparisons of the timing of key transitions (completing school, acquisition of fulltime work, marriage and cohabitation, and childbearing) across countries. Other scholars would focus on single regional or local data resources, enabling a closer and more in-depth assessment of developmental processes. The participants left the conference with resolve to continue investigating youth outcomes in the aftermath of the Great Recession, to acquire funding for future research endeavors, to initiate collaborative studies, to heighten awareness of the plight of young people in recessionary times, and to stimulate additional research by highlighting the work of the YGR Initiative at future scholarly meetings.

To this end, I organized two sessions at multidisciplinary international conferences that featured the work of scholars affiliated with the Initiative--at the Biennial Meeting of the Society for Research on Adolescence in March 2012 in Vancouver, and at the Annual Meeting of the Society for Longitudinal and Life Course Studies in Paris in September 2012. Based on four papers presented at these meetings, I proposed a "Special Section" of Longitudinal and Life Course Studies, and invited two of the leaders of the 
Youth in the Great Recession Initiative, Walter Heinz and Robert Crosnoe, to comment on them. The contributors to this Special Section represent scholars from all three countries targeted as the focus of the YGR: Germany, Great Britain, and the United States.

Three of the articles in this issue emphasize the "linked lives" of parents and children, how children are affected when families confront hard economic times. The first two (Mortimer, Zhang, Hussemann \& $\mathrm{Wu}$; Schoon) address processes of inter-generational transmission of attitudes and behaviors in the United States and England, respectively. The third (GrohSamberg \& Voges) assesses the impacts of parental support in protecting young adults in difficult economic times from experiencing poverty in Germany. The fourth article in this Special Section (Staff, Johnson, Patrick, \& Schulenberg) examines the effects of recessionary times on young people directly, by describing the consequences of the Great Recession for the labor market opportunities of contemporary American teenagers. It reveals large cohort differences in the part-time employment of high school students, a highly formative experience in the preparation for adult work. Commentaries on the four articles are provided by Professors Heinz and Crosnoe. In the following paragraphs, I highlight key findings and integrative themes.

Mortimer, Zhang, Hussemann, and Wu (this issue) assess how parental financial hardship influenced children's orientations to their futures in the aftermath of the Great Recession (2009-2011) in the American Midwest. Drawing on data from 345 matched pairs of parents and children (age 11 and older) in the longitudinal Youth Development Study, they examine the effects of parental economic stress on children's educational aspirations and economic expectations. These orientations, which motivate agentic striving and goal attainment, have strong implications for children's future educational and occupational achievement as well as otherwise successful transitions to adulthood (Grabowski, Call, \& Mortimer, 2001; Lee \& Mortimer, 2009). The authors ask, do children's educational aspirations and confidence in their capacity to succeed in the economic realm diminish when their parents suffer economic strain? They also investigate whether the familial context of achievement affects children's response to the family's economic circumstances.
Parental achievement orientations, measured in adolescence, and parental educational attainment are considered indicators of the family achievement climate, potential precursors of achievement orientations in the next generation, as well as moderators of the effects of financial hardship. Because the parents had been surveyed from the ages of 14 to 38 , the investigators were also able to assess whether prior parental unemployment experience during the decade preceding the recession conditioned the effects of more recent economic hardship. Finally, the availability of longitudinal data from both parents and children enabled estimation of first difference models, controlling stable features of parents and children and strengthening causal inference.

Mortimer and her colleagues find evidence that the familial achievement context does moderate the children's response to the family's economic circumstances. Children's economic expectations rose with their parents' incomes, but high parental expectations, measured during the parents' adolescence, heightened the impact of change in household income on change in their children's anticipated economic prospects. Furthermore, high parental aspirations during adolescence protected children from diminished educational aspirations when parents experienced financial problems. Apparently, those factors that enhance feelings of confidence and promote high educational aspirations during adolescence have long-term consequences, buffering the impacts of economic losses in the next generation.

Moreover, when parental reports of financial problems increased, economic expectations declined among children of the least well-educated parents. When parents experienced unemployment during the ten years prior to the recent recession, children's educational aspirations declined as their families' household incomes diminished. While many children appeared to be quite resilient in the face of their parents' economic struggles, children whose parents had a history of employment instability and the least educational credentials, were apparently more vulnerable.

Ingrid Schoon (this issue), drawing on data from close to 10,000 participants in the Longitudinal Study of Young People in England (born in 1989-1990) also 
examines the "linked lives" of parents and children in difficult economic times. She assesses the impacts of parental short-term and persistent worklessness on young adult children's educational achievement orientations, measured at age 16, and their experience of being NEET (not in education, employment or training) from the age of 16 to 20, after completing compulsory formal education. Parental temporary and persistent worklessness was measured just prior to the Great Recession (2004 to 2006); offspring NEET status was gauged during a five-year period including pre-recession, recession, and post-recession periods (2006 to 2010). Strikingly, this research shows that a substantial minority of children in England live in "workless" families - $14 \%$ either persistently or temporarily. It should be noted that this figure underestimates the true extent of children's exposure to unemployment. Excluded from the definition are families in which only one parent is unemployed in two-parent families, since for a family to be considered "workless", neither parent could have a job.

Like the research by Mortimer and her colleagues, Schoon's study demonstrates that parental economic fortunes have significant effects on offspring achievement orientations. She shows strong associations between parental worklessness, on the one hand, and children's achievement orientations at age 16 and months of NEET status, on the other. That is, both sons and daughters had lower educational aspirations and plans and experienced more months in NEET if their parents were either temporarily or persistently workless during their teen years. Interestingly, however, the associations between parental worklessness and these outcomes diminished considerably when other risk factors facing families were included in the models. For example, low parental education, living in a rental unit (rather than owning one's home) and neighborhood deprivation increased time spent as NEET for both males and females. In contrast, the child's earlier academic performance (age 11) in math, English and science and the child's educational aspirations and intentions to attend University (at age 16) significantly reduced the risk of NEET. These findings suggest that parents who experience unemployment are also likely to reside in neighborhoods lacking employment opportunities and other positive influences on school-leavers. Their children have low levels of educational attainment early on, and have low educational aspirations. Importantly, the child's achievement orientation moderated the effects of parental worklessness on months of NEET; children with high achievement orientations in persistently workless households had particularly low levels of NEET. Schoon's research highlights the importance of the social context in increasing the risk of NEET, and the child's own achievement orientations as protective.

Olaf Groh-Samberg and Wolfgang Voges (this issue) use matched parent and adult child data from close to 35,000 participants in the German SocioEconomic Panel Study (SOEP), surveyed well before (1984) and through the aftermath (2011) of the Great Recession. Their focus is on youth poverty, which increased substantially from 1995 to 2005, but leveled off in the most recent period from 2005 to 2011 despite the "Great Recession." They note that German youth have been protected from high unemployment rates by the dual educationemployment system. Still, long-term changes in patterns of transition to adulthood and in the labor market have increased youth vulnerability to poverty, as young people take longer to complete their educations and to form independent households with the potential for two earners.

But like the articles by Mortimer et al. and by Schoon, Groh-Samberg and Voges highlight the importance of the social context in moderating the effects of economic decline on young people. They highlight the differential potential for intergenerational support in higher- and lower-income families. They reason that official statistics overestimate youth poverty because high-income parents are likely to provide financial support for their transitioning children who no longer reside with them. The conventional measure defines poverty as household income divided by the number of residents (with adjustments for age) that is less than $60 \%$ of median national income. They show that if one assumes that incomes are shared across households (by calculating poverty on the basis of pooled incomes of parent and adult child households, divided by need or the number of residents in both households), the poverty rates of both 15-19 and 2025 year-old youth diminish markedly. For example, 
among 20-25 year olds, the official poverty rate is more than $50 \%$ for those with two parental participants in the SOEP; it falls dramatically to $11 \%$ when adjusted for parental income. Furthermore, the effects of transitions that are commonly thought to precipitate youth poverty, such as entering university, obtaining a precarious job, or becoming a parent, are greatly reduced.

Groh-Samberg and Voges recognize that their indicator of young adult income is likely to be overestimated, since it is probable that parents do not give as much to children living away as those residing under their own roofs. It is plausible to assume that normative ideas regarding young adult independence make large cash transfers uncomfortable for both generations (Swartz, 2009). Still, it is useful to highlight the potential for middle and upper class parents, in the context of hard economic times, to buffer the effects of transitions on their adult children's well-being through cash transfers (Swartz, et al., 2011).

Turning to the direct effects of the recession on youth, rather than those transmitted through parental hardship or financial support, Staff, Johnson, Patrick, and Schulenberg (this issue) examine the impacts of the Great Recession on student part-time employment in the United States. While the consequences of employment for such teenagers are the subject of much controversy (Staff, Mont'Alvao, and Mortimer, forthcoming), it is fairly well established that teenage employment can have multiple beneficial effects under the right conditions (e.g., limited working hours, good supervisory relationships, etc.). Early jobs can provide valuable socialization experiences that enhance vocational development and help to prepare youth for adult work (Mortimer, 2003). Utilizing Monitoring the Future's cohort-sequential design, the authors compare the experiences of $8^{\text {th }}, 10^{\text {th }}$, and $12^{\text {th }}$ graders in 2006-07, prior to the recession, in 2008-09, during the recession, and in 2010-11, following the recession. Merging samples across grade levels and years yielded a nationally representative sample of more than 200,000 students. While teenage employment has been declining since the 1980s, the authors show further substantial reductions during the "Great Recession," which continued in the postrecession period. Among $12^{\text {th }}$ graders, who experienced the most substantial increases in worklessness, the proportion who were not employed increased from $27 \%$ in the pre-recession period to $40 \%$ in the post-recession period. A general withdrawal from employment was observed across age, gender, and parental education categories, and among students with high and low educational expectations. Suggesting the greater importance of lower employer demand than youth's declining interest in work, approximately $88 \%$ of non-working youth wished they had a job. Moreover, the fact that young people have become increasingly concentrated over time in "youth jobs" (babysitting, yardwork) rather than in clerical, sales, and office work, suggests increasing competition from adult workers.

Although increases in youth joblessness have increased across the board, the lowest rates, before, during, and following the recession were found among minorities - African Americans and Hispanics, rather than whites. The dearth of work among these young people is particularly ominous, for they are increasingly deprived of the opportunities for human capital development that come along with gainful employment.

Staff and his colleagues show that adolescent adaptation to family hardship in the Great Recession is unlikely to include gainful work that supplements family income. Elder emphasized in his path-breaking work that children during the Great Depression, particularly boys, could help their families at a time of economic crisis through their contributions to family income. Unlike countries, such as Germany, Austria, Denmark, and Switzerland, where combinations of schooling and working are coordinated and highly regulated by the apprenticeship system, it has been normative, throughout U.S. history, for teenagers to be employed part-time during the school year in freemarket employment. In fact, contemporary cohorts of young people are much less likely than their parents or grandparents to have substantial work experience prior to entering the full-time labor force. Whereas Elder saw the benefits of working, in increasing youth confidence and work motivation, as a "silver lining" amidst Depression hardship, judging from the articles in this "Special Section", adolescents today are subject to considerable cost (in depressed aspirations and economic expectations, increased vulnerability to NEET, and risk of poverty) linked to 
their families' economic hardship, but at the same time contemporary youth are deprived of a major coping resource in addressing their families' plight.

Taken in tandem, these studies highlight the complexity of social causation. As Schoon points out, a developmental contextual perspective is sorely needed. Economic hardship at the societal level does not have uniform consequences, irrespective of the social context in which it occurs. The attributes of the family and the youth labor force are crucially important. The family's level of vulnerability, as indicated by prior parental unemployment, low parental educational credentials, and a negative climate for achievement, influences children's reactions to economic stress (Mortimer, et al., this issue). Familial worklessness is likely to be accompanied by low parental education, living in rental units, and neighborhood conditions that heighten deprivation; these fully mediate the effects of parents' worklessness on children's experience of NEET (Schoon, this issue). The economic hardship experienced by children who are making transitions to independent living, higher education, and precarious work are likely to be considerably buffered by their families' level of affluence (Groh-Samberg \& Voges, this issue). Finally, contemporary children whose parents suffer job loss may be particularly disadvantaged, in comparison with prior cohorts, because they are not able to find gainful work (Staff, et al., this issue). Hopefully, the articles in this Special Section will encourage other researchers to mine their longitudinal and comparative data sets, so as to further understanding of the consequences of recessionary times in varying historical, societal and familial contexts.

\section{References}

Alderman, L. (2013). Young and skilled, a generation stagnates in Europe's job crisis. New York Times, November 15, 2013. http://www.nytimes.com/2013/11/16/world/europe/youth-unemployement-ineurope.html? $r=0$ retrieved November 26, 2013.

Children's Defense Fund. (2011). The deterioration in the labor market fortunes of America's Young Adults during the lost decade of 2000-2011. CDF Policy Brief \#2. September 2011. http://www.childrensdefense.org/child-research-data-publications/the-deterioration-in-the.pdf retrieved December 2, 2013.

Crosnoe, R. (2014). Youth, economic hardship, and the worldwide Great Recession. Longitudinal and Life Course Studies, 5, 199-204. http://dx.doi.org/10.14301/llcs.v5i2.296

Elder, G. H. (1974). Children of the great depression: Social change in life experiences. Chicago, IL: University of Chicago Press.

Elder, G. H., Johnson, M., \& Crosnoe, R. (2003). The emergence and development of life course theory. In J. T. Mortimer \& M. J. Shanahan (Eds.), Handbook of the Life Course (pp. 3-19). New York, NY: Springer. http://dx.doi.org/10.1007/978-0-306-48247-2 1

Elder, G. H., \& Rockwell, R. C. (1979). Economic depression and postwar opportunity in men's lives: A study of life patterns and health. In R. G. Simmons (Ed.), Research in Community and Mental Health (Vol. 1, pp. 249-303). Greenwich, CT: JAI Press.

Grabowski, L. S., Call, K.T., \& Mortimer, J.T. (2001). Global and economic self-efficacy in the educational attainment process. Social Psychology Quarterly 64,164-179. http://dx.doi.org/10.2307/3090131

Groh-Samberg, O., \& Voges, W. (2014). Precursors and consequences of youth poverty in Germany. Longitudinal and Life Course Studies, 5, 151-172. http://dx.doi.org/10.14301/llcs.v5i2.281

Heinz, W. R. (2014). Did the Great Recession affect young people's aspirations and reinforce social inequality? Longitudinal and Life Course Studies, 5, 189-198. http://dx.doi.org/10.14301/llcs.v5i2.288

Lee, J. C., \& Mortimer, J.T. (2009). Family socialization, economic self-efficacy, and the attainment of financial independence in early adulthood. Longitudinal and Life Course Studies, 1, 45-62.

Mortimer, J. T. (2003). Working and growing up in America. Cambridge, MA: Harvard University Press.

Mortimer, J.T., Zhang, L., Hussemann, J., \& Wu, C-Y. (2014). Parental economic hardship and children's achievement orientations. Longitudinal and Life Course Studies, 5, 105-128. http://dx.doi.org/10.14301/llcs.v5i2.271

Newman, K. (2012). The accordion family. Boomerang kids, anxious parents, and the private toll of competition. Boston, MA: Beacon Press. 
Schoon, I. (2014). Parental worklessness and the experience of NEET among their offspring. Evidence from the Longitudinal Study of Young People in England (LSYPE). Longitudinal and Life Course Studies, 5, 129-150. http://dx.doi.org/10.14301/llcs.v5i2.279

Sobotka, T., Skirbekk, V., \& Philipov, D. (2011). Economic recession and fertility in the developed world. Population and Development Revie, 37, 267-306. http://dx.doi.org/10.1111/j.1728-4457.2011.00411.x

Staff, J., Johnson, M.K., Patrick, M.E., \& Schulenberg, J. E. (2014). When Teenage Work Disappears. Longitudinal and Life Course Studies, 5, 173-188. http://dx.doi.org/10.14301/llcs.v5i2.275

Staff, J., Mont'Alvao, A., \& Mortimer, J. T. (Forthcoming). Children at work. In M. Bornstein \& T. Leventhal (Eds.), Handbook of child psychology and developmental science, Volume 4: Ecological settings and processes in developmental systems. New York: Wiley.

Swartz, T. T. (2009). Intergenerational relations in adulthood: Patterns, variations, and implications in the contemporary United States. Annual Review of Sociolog, 35, 191-212. http://dx.doi.org/10.1146/annurev.soc.34.040507.134615

Swartz, T. T., Kim, M., Uno, M., Mortimer, J.T., \& O'Brien, K. B. (2011). Safety Nets and Scaffolds: Parental support in the transition to adulthood. Journal of Marriage and Family, 73, 414-429. http://dx.doi.org/10.1111/j.1741-3737.2010.00815.x 
